\title{
MONEY AND ITS ROLE OF AFFECTING INCOME IN GCC COUNTRIES
}

\author{
Mohammad \\ Alawin \\ Department of Economics, University of Kuwait, Kuwait. \\ Email:m_alawin@hotmail.com Tel:+965-94060844.
}

Article History
Received: 6 January 2022
Revised: 10 February 2022
Accepted: 25 February 2022
Published: 8 March 2022
Keywords
Money supply
Income
GDP
Cointegration
Causality
GCC.
JEL Classification:
E4; Qo; O4.

\begin{abstract}
The effect of money on economic growth has been a debate for centuries now. Even though many economists do agree on that effect, different analyses are assumed concerning the transmission mechanism. The main focus of this study is to empirically investigate the relationship between the money supply and GDP in the Kingdom of Saudi Arabia, Kuwait, and the United Arab Emirates during the period from 1992 until 2019. The data, studied in both nominal and real terms, revealed that the GDP in each country showed dependency on money supply only in real terms. However, the results differ according to the money aggregate from which the effect arises. Similar findings were derived from cointegration and Granger causality tests. The lack of consensus of a solid effect of money on income is inconsistent with the Monetarists' view regarding the role of money in the economy.
\end{abstract}

Contribution/ Originality: The paper's main contribution is studying empirically the relationship between the money supply and GDP in three oil exporting countries (KSA, Kuwait, and UAE).

\section{INTRODUCTION}

The Gulf Corporation Council (GCC) countries has maintained an outstanding track record on development, growth, and living standards of citizens during the past decades. These countries are heavily dependent on oil, which has huge price volatility, as a main source of income. However, enormous efforts were done to diversify their economies to provide sustainability and resilience. In addition, remarkable reforms were done in areas such as human capital, transportation, infrastructure, health, education, and economic reforms were implemented to the fiscal policy. This research focuses on the monetary issue during the past three decades. Specifically, we examine the role of monetary policy through one of its main tools, money supply, and its possible impact on economic activities, especially the national income. The relationship between money supply and output is uncertain. Still there are some discussions as to whether money supply has an actual effect on economic variables, especially income. Classical economists claim that money supply has no effect on output. On the other hand, in the Monetarists opinion, money is the sole determinant of the level of the economy, especially prices. For Monetarists, money supply can affect income or output in the short run, however, in the long run, the effect of increases in money supply will end up in proportional increases in the price levels only. Keynesian theorists believe that money has a smaller role in affecting the economy. The demand side is much more important in determining the production level, employment rate, and inflation.

Therefore, the goal of this study is to investigate the role of money supply in the economies in three oil exporting countries inside the GCC area, taking into consideration all definitions of money. Primarily, the goal is to examine 
the relationship between money supply and income for the time period from 1992 to 2019 . The sample study includes Kuwait, Saudi Arabia, and UAE. Therefore, this research paper seeks to fill out the gap in the current literature by examining the relationship between money and economic growth in three oil-exporting countries and see how would such a relation differ from other countries in other regions.

The rest of this paper is organized in the following manner. Section 2 presents the literature review related to the issue of the relationship between money supply and income. Section 3 defines the data and variables of the model. Section 4 describes the empirical tests used in this study, and section 5 provides the empirical model. The findings and the discussion of this research are provided in section 6 . Finally, section 7 concludes the paper.

\section{LITERATURE REVIEW}

In this section, we study in depth the different opinions regarding the nature of the relationship between money supply and income or GDP. We divide this section into parts. The first part includes those opinions that support a strong relationship between money supply and income. The second part details the debate from those who could not find a significant relationship among the variables of interest in this research.

\section{a) There is a Relationship}

Mansoor et al. (2018) examined the casual and long-run relationship between money supply, prices, and economic growth in Pakistan for the time period 1980-2016. Using the Autoregressive Distributed Lag (ARDL) model, the main conclusion was there is a long-run relationship between all three variables of money supply, income, and GDP, especially when broad money supply is used. The results prove that economic growth has a positive impact and prove the causality effect of money supply.

Hussain and Haque (2017) tried to find the relationship between money supply and economic growth as represented by per capita GDP growth in Bangladesh for the time period 1972-2014. The results, in the long-run and the short run, show that money supply has a crucial influence on output. Similarly, Aslam (2016) examined the impact of money supply on the economy of Sri Lanka for the period 1959-2013. The results showed that money supply held a significant positive impact on economic growth.

For the Central African Economic and Monetary Community, Njimanted, Akume, and Mukete (2016) discovered that monetary policy tools can positively influence economic growth. A similar result was found by Chaitip, Chokethaworn, Chaiboonsri, and Khounkhalax (2015) who examined the relationship between money supply and economic growth in some countries inside ASEAN Economic Cooperation for the period 1995-2013.

From the period 1980-2012, Havi and Enu (2014) inspected the effect of money supply on the economy of Ghana. The main conclusion was that money supply would significantly affect economic in growth in Ghana. To assess the correlation between money growth and output growth in the OECD countries, Sturgill (2014) used vector autoregressions and Granger Causality tests. Primarily, Sturgill found that nominal money can accelerate capital growth. Babatunde and Shuaibu (2011) questioned whether monetary expansion would provide an incentive to economic growth. Using error correction mechanism (VECM) and ARDL models, the study revealed that there is a positive relationship between capital stock, money supply, and economic growth in Nigeria. A similar conclusion was found later by Enyim, Onwe, and Okoro (2013) who studied the Nigerian economy for the period (1980-2009).

Other researchers also confirmed the positive effect of money supply, and monetary policy generally, on economic growth. Agbonlahor (2014) studied the UK economy for the period 1940-2012; Omodero (2019) studied the economy of Ghana for the period 2009 to 2018; Ingabire et al. (2020) studied the economy of Rwanda during the period (20082018); and Jawaid, Qadri, and Ali (2011) examined the case of Pakistan for the period 1981-2009. All of these researchers found a positive effect of money supply on economic growth. Finally, Senbet (2011) examined the effect of monetary policy on the US economy for the period 1959-2010. The results are generally consistent with the Monetarists view; they showed a significant effect of monetary policy on the American economy. 
On the other hand, a different result found for the case of Indonesia. Specifically, Prihatin, Arintoko, and Suharno (2019) examined the influence of monetary variables on economic growth in Indonesia and found that money supply had a significant but negative effect on economic growth. This strange result was disproved by Hasan (2021) who was not able to find a relationship between money supply and GDP for the case of Indonesia due to model weakness especially when money supply is added to the empirical model.

\section{b) No Relationship}

On the other hand, many studies disagreed with the Monetarists' view. Those studies did not find enough support for the impact of money supply on income. Inam and Ime (2017) examined the effect of monetary policy instruments on economic growth in Nigeria for the period 1970-2012. Similarly, Omodero (2019) showed that broad money supply (M2) has an insignificant negative influence on Real GDP in Nigeria. These results contradicted the findings of Babatunde and Shuaibu (2011) and Enyim et al. (2013); Inam and Ime proved a positive but insignificant relationship between money supply and economic growth. In addition, their results showed no causality between the two variables of interest. Masih and AbdulKarim (2014) studied the relationship among different macroeconomic variables for the Nigerian economy for the period 1970-2012. Output and money supply were among those variables. The results of Masih \& AbdulKarim were consistent with the findings of Inam and Ime (2017) in that money supply has not proven that it can affect economic growth positively in Nigeria.

To remove any confusion about the nature of the relationship between money supply and output, Qadeer (2016) used Pesaran Bound Testing and the ARDL model. Qadeer's study concluded that this relationship is insignificant, especially in the short run. The author urged Indian government to find tools, other than money supply, to increase economic growth in the long-run.

Precious and Makhetha-Kosi (2014) studied the effect of monetary policy in enhancing economic growth in South African for the time period 2000-2010. The study proved the long run relationship between the variables. However, the main conclusion was that money supply is insignificant in affecting economic growth. Similarly, Kamaan (2014) evaluated the effect of monetary policy on economic growth in Kenya. He discovered that monetary policy had an insignificant effect on the economy in Kenya, especially in the short run.

In summary, we found two opposing views regarding the relationship between money supply and output. Some argue that the relationship does exist, is significant, and is positive. Others found, at most, an insignificant relationship. These different views and different results are expected, since the previous literature used different countries, different time periods, and even different methodologies. In our research, we examine the nature of this relationship in three GCC countries. This study is unique in that it uses 4 different definitions of money supply to confirm whether we can support or oppose the Monetarists' view.

\section{DATA AND VARIABLES’ DESCRIPTIONS}

This paper forms a reduced-type model in order to learn about the relationship between the Money Supply (M) and the Gross Domestic Product (GDP). The economies under study are those of the Kingdom of Saudi Arabia (KSA), Kuwait (KWT), and the United Arab Emirates (UAE). Annual data from 1992 until 2019 are used for GDP and Money Supply. GDP data are collected from the World Bank. Data for money supply are collected from the central bank of each country. As for Money Supply, we focus on three types of monetary aggregates; M1, M2, and M3. Further differentiation among them is provided in the following discussion. M1 is referred to as money supply, and it consists of currency in circulation (Mo) plus deposit money. M2 is referred to as broad money supply, and it equals M1 plus savings deposits. M3 equals M2 plus local and foreign government deposits, and for some countries, it includes repurchase agreements and debt securities.

This study also examines the relationship between the variables removing the effect of inflation. Real data are derived using the GDP Deflator, as shown in Equation 1: 


$$
\text { Real Value }=\frac{\text { Nominal Value }}{\text { GDP Deflator } / 100}
$$

The data for GDP Deflator are collected from the World Bank for all three countries. Finally, we will use the natural logarithm of all of the variables in the regression. This transformation will eliminate the autocorrelation and heteroskedasticity that might be present and affect the soundness of the results. Moreover, log transformation reduces the variances in the data (Koopman \& Lee, 2009).

\section{THE EMPIRICAL TESTS}

\section{a. Test for Unit Root}

Time series usually suffer from non-stationarity of the mean because of the trending behaviour exhibited by these series. The starting point when undergoing an econometric analysis is to determine the form of the trend in the time series and work on removing it by differencing the data. This procedure will mitigate erroneous results from a spurious regression.

Choosing the right unit root test to adopt often depends on the preference of the analyst. However, Arltová and Fedorová (2016) tested the optimality of several unit root tests according to the number of observations in an attempt to make the decision more objective. With several observations equal to 28 , they found that the suitable tests for very short time series, estimated at 25 observations, are the Augmented Dickey-Fuller (ADF) and the Phillips-Perron (PP) tests. ADF test for unit root is the most common method used to test for stationarity. It is based on the Dickey and Fuller (1979) work but controls for serial correlation by counting for the lagged differences of the dependent variable. The ADF model for testing unit root is shown in Equation 2.

$$
\Delta y_{t}=\alpha+\beta y_{t-1}+\sum_{i=1}^{k} \gamma_{i} \Delta y_{t-i}+\varepsilon_{t}
$$

In Equation 2, $\Delta y_{t}$ is the first difference of $y_{t}$, with $\Delta y_{t}=y_{t}-y_{t-1} ; \alpha$ is the constant; $\beta$ is equal to $\theta-1$, with $\theta$ being a coefficient of $y_{t-1} ; \gamma$ is a parameter; $i$ is the period; and $\varepsilon$ designates the residuals or the white noise.

Table 1 contains the results of the ADF using the data for this research. These results of the output of stationarity tests are generated by Eviews software. The null hypothesis of the test is " $\beta=1$ " and the alternative hypothesis is " $\beta<1$ ". The results show that the variables are a mix of $I(1)$ and $I(2)$.

\begin{tabular}{|c|c|c|c|c|c|}
\hline Variables & t-statistic & Stationary at & Variables & t-statistic & Stationary at \\
\hline$\overline{\log Y_{K S A}}$ & $-4.621 * * *$ & $1^{\text {st }}$ Difference & $\log M 2_{\text {KSA }}$ & $-3.154^{* *} *$ & $1^{\text {st }}$ Difference \\
\hline Log $Y_{\text {KWT }}$ & $-3.993 * * *$ & $1^{\text {st }}$ Difference & $\log M 2_{\mathrm{KWT}}$ & $-6.989 * * *$ & $2^{\text {nd }}$ Difference \\
\hline $\log _{\text {UAE }}$ & $-4.522 * * *$ & $1^{\text {st }}$ Difference & $\log M 2_{\text {UAE }}$ & $-3.171 * *$ & $1^{\text {st }}$ Difference \\
\hline $\operatorname{LogRY}_{\mathrm{KSA}}$ & $-4.648 * * *$ & $1^{\text {st }}$ Difference & $\log \mathrm{RM} 2_{\mathrm{KSA}}$ & $-4.797 * * *$ & $1^{\text {st }}$ Difference \\
\hline $\log \mathrm{RY}_{\mathrm{KWT}}$ & $-5.418^{* * * *}$ & $1^{\text {st }}$ Difference & $\operatorname{LogRM} 2_{K W T}$ & $-5.105 * * *$ & $1^{\text {st }}$ Difference \\
\hline $\operatorname{LogRY}_{\mathrm{UAE}}$ & $-4.355^{* * * *}$ & $1^{\text {st }}$ Difference & $\operatorname{LogRM} 2_{\mathrm{UAE}}$ & $-3.764 * *$ & $1^{\text {st }}$ Difference \\
\hline LogM1 $1 \mathrm{KSA}$ & $-2.781 *$ & $2^{\text {nd }}$ Difference & LogM3 $3_{\mathrm{KSA}}$ & $-7.384 * * *$ & $2^{\text {nd }}$ Difference \\
\hline $\log M 1_{\mathrm{KWT}}$ & $-3.476 * *$ & $1^{\text {st }}$ Difference & LogM3 $3_{\mathrm{KWT}}$ & $-6.993 * * *$ & $2^{\text {nd }}$ Difference \\
\hline $\log M 1_{\mathrm{UAE}}$ & $-3.078 * *$ & $1^{\text {st }}$ Difference & LogM3 $3_{\mathrm{UAE}}$ & $-3.045^{* *}$ & $1^{\text {st }}$ Difference \\
\hline $\log R M 1_{K S A}$ & $-5.008 * * *$ & $1^{\text {st }}$ Difference & $\log R M 3_{K S A}$ & $-5.206^{* * * *}$ & $1^{\text {st }}$ Difference \\
\hline LogRM1 KWT & $-4.645 * * *$ & $1^{\text {st }}$ Difference & LogRM3 $3_{\text {KWT }}$ & $-5.099^{* * * *}$ & $1^{\text {st }}$ Difference \\
\hline LogRM1 $1_{\text {UAE }}$ & $-5.131 * * *$ & $1^{\text {st }}$ Difference & LogRM3UAE & $-4.483^{*} * *$ & $1^{\text {st }}$ Difference \\
\hline
\end{tabular}

Table 1. Unit root test results using ADF test.

\section{b. Engle-Granger Cointegration Test}

From an econometric perspective, it is suggested that the non-stationary time series are still able to show evidence of a long-run relationship. If the variables in question are cointegrated of order $1, I(1)$, then cointegration techniques can be applied to model this relationship. Cointegration indicates that although two or more time-series exhibit a trending behaviour, their linear combination might be stationary, and this would indicate these time-series are cointegrated (Engle \& Granger, 1987). The Engle-Granger cointegration test suggests regressing the variables 
in the first step, and then testing the residuals obtained for unit root. If the residuals are stationary at level, the variables are considered to be cointegrated and have a long-run equilibrium relationship.

To apply the Engle-Granger cointegration test, the variables need to be integrated of the same order (Bilgili, 1998). Others consider the test to have time series that are only stationary when omitting both the intercept and the trend (Bălă, 2014). In this paper, only the intercept is included within the model. The findings of our time-series are shown in Table 2.

Based on the results of the Engle-Granger residual-based test for cointegration, some series showed to be cointegrated in the long run, and some others did not. Both the models in nominal terms and the models in real terms showed the same cointegration results, except for one case. The long-run equation estimating the relationship between GDP and M1 in Kuwait differs when using nominal or real terms.

In general, a long-run relationship was seen between Saudi Arabia's GDP and both M2 and M3 monetary aggregates, in both nominal and real terms. The models tested for UAE showed that a long-run relationship exists among GDP and all the monetary aggregates, M1, M2, and M3. In the Kuwait models, there was no evidence for a long-run relationship between GDP and any other monetary aggregate, except for the case of GDP and M1. In the model using the real terms, a relationship between GDP and M1 was apparent at the 10 percent significance level. However, this relationship was not present in the model using nominal data. These results highlight how data specification and model choice can vary results.

Table 2. Results of the Engle-granger cointegration test.

\begin{tabular}{|c|c|c|c|c|}
\hline 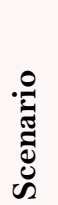 & Dependent Variable & Explained by & $\begin{array}{l}\text { Dickey-Fuller } \\
\text { Test Statistic }\end{array}$ & 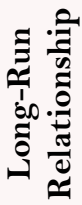 \\
\hline $1 \mathrm{~A}$ & $\log Y_{\mathrm{KSA}}$ & $\log M 1_{K S A}$ & -2.271 & $\mathrm{No}$ \\
\hline $1 \mathrm{~B}$ & $\log Y_{K S A}$ & $\log M 2_{\mathrm{KSA}}$ & $-2.681^{*}$ & Yes \\
\hline $1 \mathrm{C}$ & $\log Y_{K S A}$ & $\log M 3_{\mathrm{KSA}}$ & $-2.982^{* *}$ & Yes \\
\hline $2 \mathrm{~A}$ & $\log Y_{\text {KWT }}$ & $\log M 1_{K W T}$ & -2.086 & No \\
\hline $2 \mathrm{~B}$ & LogY $Y_{\text {KWT }}$ & $\log M 2_{K W T}$ & -2.049 & $\mathrm{No}$ \\
\hline $2 \mathrm{C}$ & $\log Y_{K W T}$ & LogM3 ${ }_{\mathrm{KWT}}$ & -2.089 & $\mathrm{No}$ \\
\hline $3 \mathrm{~A}$ & $\log Y_{\text {UAE }}$ & $\log M 1_{\text {UAE }}$ & $-2.922^{*}$ & Yes \\
\hline $3 \mathrm{~B}$ & $\log Y_{\text {UAE }}$ & LogM2 $2_{\text {UAE }}$ & $-3.381^{*} *$ & Yes \\
\hline $3 \mathrm{C}$ & Log $Y_{\text {UAE }}$ & LogM3UAE & $-3.364 * *$ & Yes \\
\hline $4 \mathrm{~A}$ & $\log _{R} Y_{\mathrm{KSA}}$ & $\operatorname{LogRM} 1_{\mathrm{KSA}}$ & -2.606 & $\mathrm{No}$ \\
\hline $4 \mathrm{~B}$ & $\log R Y_{K S A}$ & $\operatorname{LogRM} 2_{\mathrm{KSA}}$ & $-3.061^{* *}$ & Yes \\
\hline $4 \mathrm{C}$ & $\log R Y_{K S A}$ & $\operatorname{LogRM} 3_{\mathrm{KSA}}$ & $-3.28^{* *}$ & Yes \\
\hline $5 \mathrm{~A}$ & LogRY $_{\mathrm{KWT}}$ & $\log R M 1_{K W T}$ & $-2.809^{*}$ & Yes \\
\hline $5 \mathrm{~B}$ & LogRY $Y_{K W T}$ & $\log R M 2_{K W T}$ & -2.351 & $\mathrm{No}$ \\
\hline $5 \mathrm{C}$ & $\operatorname{LogRY}_{\mathrm{KWT}}$ & LogRM3KWT & -2.413 & $\mathrm{No}$ \\
\hline $6 \mathrm{~A}$ & $\operatorname{LogRY}_{\text {UAE }}$ & LogRM $1_{\text {UAE }}$ & $-2.905^{*}$ & Yes \\
\hline $6 \mathrm{~B}$ & LogRY UAE & $\log \mathrm{RM} \mathcal{2}_{\mathrm{UAE}}$ & $-3.36^{* * *}$ & Yes \\
\hline $6 \mathrm{C}$ & $\log R Y_{\text {UAE }}$ & LogRM3UAE & $-3.253^{* *}$ & Yes \\
\hline
\end{tabular}

\section{c. Johansen Test for Cointegration}

Another method to test for the existence of a long run relationship or the ability to estimate a cointegration equation is the Johansen test (Johansen, 1991). The test was developed to overcome the limitation of the EngleGranger test, which restricts the number of variables to a maximum of two. The Engle-Granger test is unable to detect more than one cointegration equation. The Johansen test can be used for testing two variables.

There are two types of Johansen cointegration tests: the Trace test and the Maximum Eigenvalue test. It is likely that researchers would get the same results in both tests. However, it is for them to accept one over another. The 
Trace test aims at estimating the number of cointegrating vectors (the cointegration rank), $r$. The null hypothesis, $\mathrm{H}_{0}$, for the trace statistic test is that the number of cointegration vectors is less than or equal to $r$, and the alternative hypothesis, $\mathrm{H}_{\mathrm{A}}$, is that cointegrating vectors exactly equal $r$. The Maximum Eigenvalue statistic has $\mathrm{H}_{0}$ is that $r$ cointegration vectors exist and $\mathrm{H}_{\mathrm{A}}$ is that $r=1$ (Alawin, 2013).

The likelihood ratio test for the trace statistic is given by:

$$
L R_{\text {trace }}(r)=-T \sum_{i=r+1}^{n} \ln \left(1-\hat{\lambda}_{i}\right)
$$

Where $\hat{\lambda}_{r+1}, \ldots, \hat{\lambda}_{P}$ are the $p-r$ smallest estimated eigenvalues.

The decision to adopt the Trace test avoids contradicting results among the two statistics. Also, Lütkepohl, Saikkonen, and Trenkler (2001) studied and compared the two tests in question using a variety of deterministic tests. They found, in small samples, that in some situations, the Trace tests showed a tendency to have more heavily distorted sizes. However, the Trace tests' power performance showed to be superior to the Maximum Eigenvalue. The computed values for the Trace test of the Johansen test for cointegration are shown in Table 3.

Table 3. Results of the trace for Johansen cointegration test.

\begin{tabular}{|c|c|c|c|c|c|c|c|c|}
\hline \multirow[b]{2}{*}{ 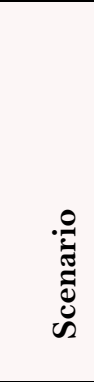 } & \multirow[b]{2}{*}{$\begin{array}{c}\text { Dependent } \\
\text { Variable }\end{array}$} & \multirow[b]{2}{*}{$\begin{array}{c}\text { Explained } \\
\text { by }\end{array}$} & \multicolumn{4}{|c|}{ Trace Test } & \multirow{2}{*}{ בే } & \multirow{2}{*}{ 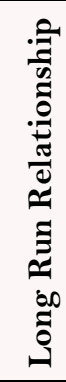 } \\
\hline & & & None & $\begin{array}{l}\frac{\Xi}{0} \\
. \frac{\pi}{0} \\
\stackrel{0}{0}\end{array}$ & 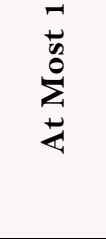 & $\begin{array}{l}\frac{\Xi}{0} \\
. \frac{\pi}{0} \\
\stackrel{0}{0}\end{array}$ & & \\
\hline $1 \mathrm{~A}$ & $\log \mathcal{Y}_{K S A}$ & $\log M 1_{K S A}$ & $17.997^{*}$ & Reject & 0.878 & Accept & One & Yes \\
\hline $1 \mathrm{~B}$ & $\log \mathcal{Y}_{K S A}$ & $\log M 2_{K S A}$ & 8.033 & FTR & 1.167 & Accept & None & $\mathrm{No}$ \\
\hline $1 \mathrm{C}$ & $\log \mathcal{Y}_{K S A}$ & $\log M 3_{K S A}$ & 14.65 & FTR & 0.443 & Accept & None & $\mathrm{No}$ \\
\hline $2 \mathrm{~A}$ & $\log \mathcal{Y}_{K W T}$ & $\log M 1_{K W T}$ & 7.718 & FTR & 1.081 & Accept & None & $\mathrm{No}$ \\
\hline $2 \mathrm{~B}$ & $\log \mathcal{Y}_{K W T}$ & $\log M 2_{K W T}$ & 13.134 & FTR & 0.741 & Accept & None & $\mathrm{No}$ \\
\hline $2 \mathrm{C}$ & $\log \mathcal{Y}_{K W T}$ & $\log M 3_{K W T}$ & 13.368 & FTR & 0.739 & Accept & None & No \\
\hline $3 \mathrm{~A}$ & $\log \mathcal{Y}_{U A E}$ & $\log M 1_{U A E}$ & 13.919 & FTR & 1.145 & Accept & None & No \\
\hline $3 \mathrm{~B}$ & $\log \mathcal{Y}_{\text {UAE }}$ & $\log M 2_{U A E}$ & $22.102^{*}$ & Reject & 2.193 & Accept & One & Yes \\
\hline $3 \mathrm{C}$ & $\log \mathcal{Y}_{U A E}$ & $\log M 3_{\text {UAE }}$ & $18.315^{*}$ & Reject & 1.771 & Accept & One & Yes \\
\hline $4 \mathrm{~A}$ & $\log R \gamma_{K S A}$ & $\log R M 1_{K S A}$ & 6.618 & FTR & 0.001 & Accept & None & No \\
\hline $4 \mathrm{~B}$ & $\log R \Upsilon_{K S A}$ & $\log R M 2_{K S A}$ & 10.557 & FTR & 0.017 & Accept & None & $\mathrm{No}$ \\
\hline $4 C$ & $\log R \Upsilon_{K S A}$ & $\log R M 3_{K S A}$ & 10.886 & FTR & 0.038 & Accept & None & $\mathrm{No}$ \\
\hline $5 \mathrm{~A}$ & $\log R \Upsilon_{K W T}$ & $\log R M 1_{K W T}$ & 3.898 & FTR & 0.712 & Accept & None & $\mathrm{No}$ \\
\hline $5 \mathrm{~B}$ & $\log R \Upsilon_{K W T}$ & $\log R M 2_{K W T}$ & 6.633 & FTR & 1.135 & Accept & None & No \\
\hline $5 \mathrm{C}$ & $\log R \mathcal{Y}_{K W T}$ & $\log R M 3_{\kappa W T}$ & 6.756 & FTR & 1.138 & Accept & None & $\mathrm{No}$ \\
\hline $6 \mathrm{~A}$ & $\log R \mathcal{Y}_{\text {UAE }}$ & $\log R M 1_{\text {UAE }}$ & 11.387 & FTR & 1.833 & Accept & None & $\mathrm{No}$ \\
\hline $6 \mathrm{~B}$ & $\log R \Upsilon_{U A E}$ & $\log R M 2_{U A E}$ & $17.976^{*}$ & Reject & 3.554 & Accept & One & Yes \\
\hline $6 \mathrm{C}$ & $\log R \mathcal{Y}_{\text {UAE }}$ & $\log R M 3_{\text {UAE }}$ & $22.371^{*}$ & Reject & 3.562 & Accept & One & Yes \\
\hline
\end{tabular}

Note: *Significant at 0.05 critical value, indicating one cointegrating equation at the 0.05 level.

FTR designates Failed to Reject the null hypothesis $\left(\mathrm{H}_{0}\right)$.

Based on the results Table 3, some of the pair variables showed to have a one cointegrating equation. In general, a long run relationship is detected between Saudi Arabia's GDP and M1 monetary aggregate. This contradicts with the results derived from the previous Engle-Granger causality test. Also, the two tests disagree regarding the real term variables in Saudi Arabia; the Trace test failed to detect any relationship. 
The Johansen test also failed to detect any long-term relationship between GDP and money supply aggregates in Kuwait, in both nominal and real terms. This validates the results of the previous cointegration test, except the one in real terms for GDP and M1 money supply. Therefore, both cointegration tests agree on the same decision for the case of Kuwait, when considering a 5 percent significance level.

The case is the same among the UAE variables tested. A long run relationship was seen on the levels of M2 and M3 monetary aggregates, in nominal and real terms. These results were validated previously by the Engle Granger test. However, the pair of GDPs with M1, in both real and nominal terms, showed to difference between the two tests, which can be attributed to using a 10 percent level of significance in the Engle-Granger test and a 5 percent level of significance in the Johansen test. When testing for cointegration using the Johansen test, both Trace and Maximum Eigenvalue tests revealed the same results. This may indicate that even if this research adopted the Maximum Eigenvalue results, the contradiction between the Engle-Granger and Johansen tests may still be present. This point should be taken into consideration by policy makers when making future decisions potentially based on this research.

\section{d. Granger Causality Test}

Given the existence of cointegration, it is very beneficial to test causality among the GDP and Money Supply, both in nominal and real terms. Granger (1969) proposed a statistical concept to test for a causality relationship based on prediction. Based on Granger's findings, if $M$ causes $\mathcal{Y}$, then the prediction of $\mathcal{Y}$ should be based on the previous values of $Y$ and the previous values of $M$. This method can be superior to the prediction power of the past values of $Y$ alone. Since our study is limited to two variables, income and money supply, it is sufficient to employ a bivariate Granger causality model. The corresponding linear models are presented in Equations 3 and 4.

$$
\begin{aligned}
& Y_{t}=\sum_{i=1}^{n} \mu_{i} M_{t-i}+\sum_{j=1}^{n} \theta_{j} Y_{t-j}+u_{1 t} \\
& M_{t}=\sum_{i=1}^{n} \gamma_{i} M_{t-i}+\sum_{j=1}^{n} \delta_{j} M_{t-j}+u_{2 t}
\end{aligned}
$$

\begin{tabular}{|c|c|c|c|c|c|c|c|c|}
\hline \multirow[b]{2}{*}{ 赵 } & \multicolumn{2}{|c|}{ Granger Causality between } & \multicolumn{2}{|c|}{ Lag 1} & \multicolumn{2}{|c|}{ Lag 2} & \multicolumn{2}{|c|}{ Lag 3} \\
\hline & $\begin{array}{l}\frac{4}{0} \\
\frac{0}{0} \\
\frac{\pi}{\pi} \\
\frac{\pi}{\pi}\end{array}$ & 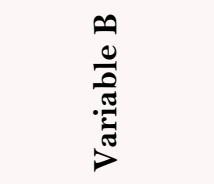 & $\underbrace{\frac{0}{J}}_{\substack{1 \\
\frac{\pi}{J}}}$ & 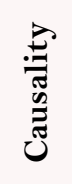 & 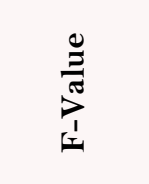 & 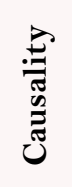 & 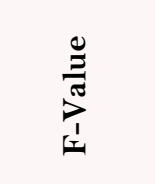 & 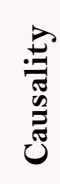 \\
\hline \multirow{2}{*}{$1 \mathrm{~A}$} & $D D \log M 1_{K S A}$ & $D \log \Upsilon_{K S A}$ & $5.039^{*}$ & Yes & 2.371 & $\mathrm{No}$ & 1.456 & $\mathrm{No}$ \\
\hline & $D \log \Upsilon_{K S A}$ & $D D \log M 1_{K S A}$ & 0.030 & No & 0.129 & No & 0.358 & No \\
\hline \multirow{2}{*}{$1 \mathrm{~B}$} & $D \log M 2_{K S A}$ & $D \log \Upsilon_{K S A}$ & 0.166 & No & 0.263 & No & 0.164 & No \\
\hline & $D \log \Upsilon_{K S A}$ & $D \log M 2_{K S A}$ & 0.928 & No & 1.378 & No & 2.316 & No \\
\hline \multirow{2}{*}{$1 \mathrm{C}$} & $D D \log M 3_{K S A}$ & $D \log \Upsilon_{K S A}$ & 0.166 & No & 0.114 & No & 0.700 & No \\
\hline & $D \log \Upsilon_{K S A}$ & $D D \log M 3_{K S A}$ & $3.272^{*}$ & Yes & 1.584 & No & 0.371 & No \\
\hline \multirow{2}{*}{$2 \mathrm{~A}$} & $D \log M 1_{K W T}$ & $D \log Y_{K W T}$ & $3.238^{*}$ & Yes & $2.607 *$ & Yes & 3.120* & Yes \\
\hline & $D \log \Upsilon_{K W T}$ & $D \log M 1_{K W T}$ & 0.171 & No & 0.259 & No & 0.189 & $\mathrm{No}$ \\
\hline \multirow{2}{*}{$2 \mathrm{~B}$} & $D D \log M 2_{K W T}$ & $D \log \Upsilon_{K W T}$ & 0.038 & No & 0.969 & No & 0.781 & $\mathrm{No}$ \\
\hline & $D \log \Upsilon_{K W T}$ & $D D \log M 2_{K W T}$ & $7.622^{* *}$ & Yes & $6.077 * * *$ & Yes & $5.369^{* * * *}$ & Yes \\
\hline \multirow{2}{*}{$2 \mathrm{C}$} & $D D \log M 3_{\kappa W T}$ & $D \log \Upsilon_{K W T}$ & 0.023 & No & 0.923 & No & 0.733 & No \\
\hline & $D \log \Upsilon_{K W T}$ & DDLogM ${ }_{\kappa W T}$ & $7.727 * *$ & Yes & $6.132 * * *$ & Yes & $5.305 * * *$ & Yes \\
\hline \multirow{2}{*}{$3 \mathrm{~A}$} & $D \log M 1_{\text {UAE }}$ & $D \log \Upsilon_{\text {UAE }}$ & 1.980 & No & $3.210^{*}$ & Yes & $4.940^{* * *}$ & Yes \\
\hline & $D \log \Upsilon_{\text {UAE }}$ & $D \log M 1_{\text {UAE }}$ & $3.232^{*}$ & Yes & 1.425 & No & 1.393 & $\mathrm{No}$ \\
\hline \multirow{2}{*}{$3 \mathrm{~B}$} & $D \log M 2_{\text {UAE }}$ & $D \log \Upsilon_{U A E}$ & $3.400^{*}$ & Yes & $5.312^{*} *$ & Yes & $4.102 * *$ & Yes \\
\hline & $D \log \Upsilon_{U A E}$ & $D \log M 2_{U A E}$ & 0.616 & $\mathrm{No}$ & 1.197 & $\mathrm{No}$ & 1.271 & No \\
\hline \multirow{2}{*}{$3 \mathrm{C}$} & $D \log M 3_{\text {UAE }}$ & $D \log \Upsilon_{\text {UAE }}$ & 2.091 & No & 1.909 & No & 1.802 & $\mathrm{No}$ \\
\hline & $D \log \Upsilon_{U A E}$ & $D \log M 3_{\text {UAE }}$ & 0.038 & No & 1.326 & No & 0.868 & No \\
\hline
\end{tabular}

Table 4A. Results of the bivariate granger causality test: Nominal variables. 
The bivariate model (3) assumes that the GDP, $Y_{t}$, is related to the past values of the GDP itself through the information stored in these past values and is related also to the values of the money supply, $M$. The model similarly assumes (4) that the money supply is predicted by the variable itself and the GDP. Tables 4A and 4B show the findings on Granger causality, as tested among the variables. To test for Granger causality, the variables must be stationary (Asghar, 2009) and Gelo (2009).

Tables 4A and 4B summarize the Granger causality test results with up to three lag years. The results also show the test in nominal terms as well as real terms. The results showed some causality running from money supply to GDP and vice versa in several cases. However, all the significant results are present in the nominal terms, whereas real-term tests did not show any causality relationship. This evidence is consistent with and approved by the work of Ahmed and Suliman (2011).

Table 4B. Results of the bivariate granger causality test: Real variables.

\begin{tabular}{|c|c|c|c|c|c|c|c|c|}
\hline \multirow[t]{2}{*}{ Scenario } & \multicolumn{2}{|c|}{ Granger Causality between } & \multicolumn{2}{|c|}{ Lag 1} & \multicolumn{2}{|c|}{ Lag 2} & \multicolumn{2}{|c|}{ Lag 3} \\
\hline & 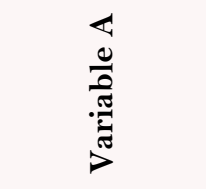 & $\frac{n}{\frac{0}{0}}$ & 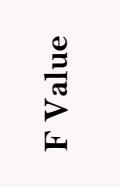 & 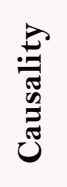 & $\underset{\sim}{\stackrel{\Xi}{\Xi}}$ & 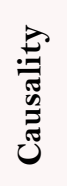 & $\underset{\square}{\stackrel{\Xi}{\Xi}}$ & 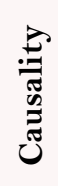 \\
\hline \multirow{2}{*}{$4 \mathrm{~A}$} & $D \log R M 1_{\kappa S A}$ & $D \log R \Upsilon_{K S A}$ & 0.880 & No & 2.123 & No & 1.039 & $\mathrm{No}$ \\
\hline & $D \log R \mathcal{Y}_{K S A}$ & $D \log R M 1_{K S A}$ & 2.082 & No & 1.031 & No & 1.002 & $\mathrm{No}$ \\
\hline \multirow{2}{*}{$4 B$} & $D \log R M 2_{K S A}$ & $D \log R \mathcal{Y}_{K S A}$ & 0.000 & No & 1.097 & No & 0.605 & $\mathrm{No}$ \\
\hline & $D \log R \Upsilon_{K S A}$ & $D \log R M 2_{K S A}$ & 2.588 & No & 1.183 & No & 1.896 & $\mathrm{No}$ \\
\hline \multirow{2}{*}{$4 C$} & $D \log R M 3_{K S A}$ & $D \log R \mathcal{Y}_{K S A}$ & 0.054 & No & 1.479 & No & 0.737 & $\mathrm{No}$ \\
\hline & $D \log R \Upsilon_{K S A}$ & $D \log R M 3_{K S A}$ & $3.211^{*}$ & No & 1.321 & No & 1.703 & $\mathrm{No}$ \\
\hline \multirow{2}{*}{$5 \mathrm{~A}$} & $D \log R M 1_{\kappa W T}$ & $D \log R \Upsilon_{K W T}$ & 0.442 & $\mathrm{No}$ & 0.520 & $\mathrm{No}$ & 0.273 & $\mathrm{No}$ \\
\hline & $D \log R \Upsilon_{K W T}$ & $D \log R M 1_{\kappa W T}$ & 0.006 & $\mathrm{No}$ & 0.645 & No & 1.060 & $\mathrm{No}$ \\
\hline \multirow{2}{*}{$5 \mathrm{~B}$} & $D \log R M 2_{K W T}$ & $D \log R \Upsilon_{K W T}$ & 1.270 & $\mathrm{No}$ & 0.552 & $\mathrm{No}$ & 0.653 & $\mathrm{No}$ \\
\hline & $D \log R \Upsilon_{K W T}$ & $D \log R M 2_{K W T}$ & 0.555 & No & 0.002 & No & 0.163 & $\mathrm{No}$ \\
\hline \multirow{2}{*}{$5 \mathrm{C}$} & $D \log R M 3_{\kappa W т}$ & $D \log R \Upsilon_{K W T}$ & 1.237 & No & 0.543 & $\mathrm{No}$ & 0.638 & $\mathrm{No}$ \\
\hline & $D \log R \Upsilon_{K W T}$ & $D \log R M 3_{\kappa W т}$ & 0.497 & No & 0.008 & $\mathrm{No}$ & 0.151 & $\mathrm{No}$ \\
\hline \multirow{2}{*}{$6 \mathrm{~A}$} & $D \log R M 1_{\text {UAE }}$ & $D \log R \Upsilon_{\text {UAE }}$ & 0.229 & No & 0.495 & No & 0.246 & $\mathrm{No}$ \\
\hline & $D \log R \Upsilon_{U A E}$ & $D \log R M 1_{\text {UAE }}$ & 9.350 & No & $4.004^{* *} *$ & No & $3.882^{* * *}$ & $\mathrm{No}$ \\
\hline \multirow{2}{*}{$6 \mathrm{~B}$} & $D \log R M 2_{U A E}$ & $D \log R \Upsilon_{U A E}$ & 0.166 & No & 0.806 & No & 0.827 & $\mathrm{No}$ \\
\hline & $D \log R \Upsilon_{U A E}$ & $D \log R M 2_{U A E}$ & $3.609^{*}$ & $\mathrm{No}$ & $3.907^{* *}$ & $\mathrm{No}$ & $2.975^{*}$ & $\mathrm{No}$ \\
\hline \multirow{2}{*}{$6 \mathrm{C}$} & $D \log R M 3_{U A E}$ & $D \log R \Upsilon_{U A E}$ & 0.201 & No & 0.993 & No & 0.784 & $\mathrm{No}$ \\
\hline & $D \log R \Upsilon_{U A E}$ & $D \log R M 3_{\text {UAE }}$ & $3.931^{*}$ & No & $3.775^{* *}$ & $\mathrm{No}$ & $2.907^{*}$ & $\mathrm{No}$ \\
\hline
\end{tabular}

The tests applied to Saudi Arabia data sets showed a significant causality emerging from M1 towards GDP and from GDP towards M3 in nominal terms at the first lag only. For Kuwait, the results were lengthier in time. M1 showed to Granger cause GDP over all three tested lags, and the GDP Granger caused both M2 and M3 over all three lags. In the UAE, evidence from the tests revealed that M1 Granger causes the GDP over the second and third lag, whereas over the first lag the effect of causality emerges from the GDP towards M1. In the UAE, M2 showed causality towards GDP in all three lags.

\section{THE EMPIRICAL MODEL}

This research employed a reduced-form model in an attempt to find the linkages between GDP and money supply and further describe on the money-income relationship. The linear model is applied in twelve scenarios for each of the three economies under study, and the general notation of the model is related in Equation 5 .

$$
Y_{t}=f\left(M_{s t}\right)
$$

Where $Y$ is the nominal output or GDP. $R Y$, therefore, denotes the real GDP. $M_{s}$ is the money supply in nominal terms and designates either $M 1$ or $M 2$ or $M 3$, as specified in the discussion. $R M_{s}$ denotes the real money supply, and $t$ is the current period. Thus, the general functional form of the estimating model is written in Equation 6. 


$$
Y_{t}=\alpha+\beta M_{s t}+\varepsilon_{t}
$$

Where $\alpha$ is the constant; $\beta$ is the parameter estimated, with $\beta \neq 0$; and $\varepsilon$ is the residual or error term.

Although the results of the cointegration tests were mixed, we will report the results of all models to demonstrate the extent to which the models show a strong relationship between money supply and income, in line with their degrees of cointegration. Limitations are discussed whenever it is necessary.

\section{FINDINGS AND DISCUSSION}

The regression results show several findings concerning the relationship between the money supply and income or GDP. In general, all the models showed a very small R-squared statistic The small values of the coefficients may be attributed to the fact that GDP cannot be explained by only one variable. The reduced-model applied intends primarily to discover the nature of the relationship between the two variables in question, provided such a relationship exists. We calculated the Durbin-Watson statistic for all the regressions. The D-W statistic was developed by Durbin and Watson (1950) and Durbin and Watson (1951) to measure the serial correlation among the residuals of a model. The test reports values ranging between zero and 4 , and 2 is considered the optimal value that confirms no autocorrelation is present. Values above 2 indicate negative correlation, and values below 2 indicate a positive correlation. As a rule of thumb, a range between 1.5 and 2.5 is considered relatively acceptable. In addition, values under 1 or exceeding 3 would be a cause of concern. The values from our models are all acceptable and showed that the residuals are uncorrelated. Therefore, the models regressed are sound in terms of autocorrelation, except in the case of Kuwait. The model using real values for Kuwait data show a positive correlation among the residuals. Generally, all the real-value models showed lower Durbin-Watson statistics compared to the nominal-value models.

The estimation for each model shows the probability value of the F-statistic, which tests the overall significance of the estimated model. A value above 0.099 will indicate a non-significant model.

\section{a. Saudi Arabia}

The following models test for the relationship between money supply and GDP in Saudi Arabia. Initially, the M1 monetary aggregate is regressed, then M2 and M3. Each variable is regressed against GDP separately. The regression is also run using data in real terms for both variables. Table 5 displays the results.

The results show that, in nominal terms, the GDP in Saudi Arabia is independent of the M1 money supply. However, M2 shows a significant positive relationship with the output income. This result might be attributed to the fact that the size of $\mathrm{M} 1$ is exogenously determined by an independent decision from the Central Bank (Chaitip et al., 2015). The decision regarding the size of the M1 money supply is likely affected by factors and variables not included in our model, such as the oil price or stock market index.

Table 5. Results of the KSA empirical model.

\begin{tabular}{|c|c|c|c|c|c|c|}
\hline \multirow{2}{*}{$\begin{array}{l}\text { Response } \\
\text { Variable }\end{array}$} & \multirow{2}{*}{$\begin{array}{c}\text { Explanatory } \\
\text { Variable }\end{array}$} & \multirow[b]{2}{*}{ Constant } & \multirow[b]{2}{*}{ Coefficient } & \multicolumn{3}{|c|}{ Test Statistics } \\
\hline & & & & R-Squared & $\begin{array}{l}\text { Durbin- } \\
\text { Watson }\end{array}$ & $\begin{array}{l}\text { P-Value for } \\
\text { F-Statistic }\end{array}$ \\
\hline DLog $Y_{K S A}$ & DDLogM $1_{\mathrm{KSA}}$ & $\begin{array}{c}0.069 * * * \\
(0.023)\end{array}$ & $\begin{array}{l}-0.131 \\
(0.326)\end{array}$ & 0.007 & 1.812 & 0.691 \\
\hline $\mathrm{DLogRY}_{\mathrm{KSA}}$ & DLogRM $1_{\mathrm{KSA}}$ & $\begin{array}{c}0.027^{*} * * \\
(0.008)\end{array}$ & $\begin{array}{l}-0.024 \\
(0.069) \\
\end{array}$ & 0.005 & 1.730 & 0.728 \\
\hline DLog $Y_{K S A}$ & $\mathrm{DLog} M 2_{\mathrm{KSA}}$ & $\begin{array}{l}-0.017 \\
(0.034)\end{array}$ & $\begin{array}{c}0.946^{* * *} \\
(0.319)\end{array}$ & 0.260 & 2.143 & 0.007 \\
\hline $\mathrm{DLogRY}_{\mathrm{KSA}}$ & $\mathrm{DLogRM} 2_{\mathrm{KSA}}$ & $\begin{array}{c}0.026^{* * * *} \\
(0.008)\end{array}$ & $\begin{array}{l}-0.016 \\
(0.081)\end{array}$ & 0.001 & 1.775 & 0.850 \\
\hline DLog $Y_{K S A}$ & DDLogM3 ${ }_{\mathrm{KSA}}$ & $\begin{array}{c}0.068 * * * \\
(0.022)\end{array}$ & $\begin{array}{c}0.650 \\
(0.449)\end{array}$ & 0.080 & 2.091 & 0.161 \\
\hline $\mathrm{DLogR}_{\mathrm{KSA}}$ & DLogRM $3_{\mathrm{KSA}}$ & $\begin{array}{c}0.028 * * * \\
(0.008)\end{array}$ & $\begin{array}{l}-0.046 \\
(0.077)\end{array}$ & 0.014 & 1.729 & 0.557 \\
\hline
\end{tabular}


On the other hand, the explanation behind the significant relationship between GDP and M2 could be because the growth in the size of the economy will lift up the size of $\mathrm{M} 2$ with it. A sound, resilient, and growing economy attracts foreign deposits, frequently time-saving deposits, and thus leads to increasing the size of M2. The growing $\mathrm{M} 2$, in turn, increases the size of GDP, as the deposits are channelled in the banking system to end up in investment. The strong and fixed exchange rate in the GCC economies is another cause for attracting foreign deposits, increasing M2, and in turn increasing GDP (Al-Jasser \& Al-Hamidy, 2004).

The M3 monetary aggregate showed no significance to the GDP in the Saudi case. M3 in Gulf countries mainly differs from the M2 broad money supply by the addition of government deposits. The amount of government deposits is another decision that is considered to be made independently by the financial authorities in the country. Their decision is based on the GDP and other factors, such as an economic crisis, a crash in the oil market, or even other times of financial difficulties. Omodero (2019) reached very similar results concerning a non-significant relationship between GDP and M3 money supply.

Finally, when tested in real terms, none of the real money supply variables showed any significant relationship with the real GDP. The decision behind testing for real income effect is to test the relationship without the effect of the inflation that might lead to an increase in income, while other factors remain unchanged.

\section{b. Kuwait}

The following are the results of models that test for the relationship between money supply and GDP in Kuwait. The M1, M2, and M3 aggregates are all tested separately. The regression is also done in real terms for both variables. Table 6 displays the results.

The results of the models estimated for Kuwait show that the GDP is significantly dependent on the money supply M1 with no significant relationship with the M2 or M3 aggregates. Such results are consistent with the findings of the causality results presented in Table 4A. The components of the $\mathrm{M} 2$ aggregate might have the answer for the lack of relationship with GDP. M2 includes deposits in foreign currencies and long-maturity deposits in national and foreign currencies, and the Kuwait national currency has always showed a pronounced stability against the USD (Marzovilla \& Mele, 2010). Therefore, changes in M2 may be the result of a change in domestic currency, a change in the local bank's claims on both the private and public sector, a change in foreign assets, or other factors. These factors could have depended on GDP, but they might also depend on other variables not included in the model.

The reason behind the significant relationship between GDP and M1 could be attributed to the fact that with the increase in M1, inflation rises, and GDP rises too. This could be supported by the results of the model estimating the real terms of GDP and M1 where no relationship was found. In fact, no evidence of a significant relationship was present in the three real-term models.

Table 6. Results of Kuwait empirical model.

\begin{tabular}{|c|c|c|c|c|c|c|}
\hline \multirow{2}{*}{$\begin{array}{l}\text { Response } \\
\text { Variable }\end{array}$} & \multirow{2}{*}{$\begin{array}{c}\text { Explanatory } \\
\text { Variable }\end{array}$} & \multirow[b]{2}{*}{ Constant } & \multirow[b]{2}{*}{ Coefficient } & \multicolumn{3}{|c|}{ Test Statistics } \\
\hline & & & & R-Squared & $\begin{array}{l}\text { Durbin- } \\
\text { Watson }\end{array}$ & $\begin{array}{l}\text { P-Value for } \\
\text { F-Statistic }\end{array}$ \\
\hline$\overline{D L o g} Y_{K W T}$ & DLogM1KWT & $\begin{array}{c}0.012 \\
(0.038)\end{array}$ & $\begin{array}{l}0.723^{*} * \\
(0.313)\end{array}$ & 0.176 & 1.733 & 0.030 \\
\hline DLogRY $Y_{K W T}$ & DLogRM $1_{K W T}$ & $\begin{array}{l}0.042^{* *} \\
(0.015)\end{array}$ & $\begin{array}{c}0.008 \\
(0.114) \\
\end{array}$ & 0.000 & 0.940 & 0.944 \\
\hline DLog $Y_{K W T}$ & DDLogM $\mathcal{2}_{\mathrm{KWT}}$ & $\begin{array}{l}0.069^{* *} \\
(0.030)\end{array}$ & $\begin{array}{c}0.798 \\
(0.586)\end{array}$ & 0.072 & 1.823 & 0.186 \\
\hline DLogR $Y_{K W T}$ & DLogRM $2_{\text {KWT }}$ & $\begin{array}{c}0.042^{* * *} \\
(0.014)\end{array}$ & $\begin{array}{c}0.007 \\
(0.109)\end{array}$ & 0.000 & 0.939 & 0.952 \\
\hline DLog $Y_{K W T}$ & DDLogM3KwT & $\begin{array}{l}0.068^{* * *} \\
(0.030)\end{array}$ & $\begin{array}{c}0.806 \\
(0.584) \\
\end{array}$ & 0.074 & 1.823 & 0.180 \\
\hline DLogR $Y_{K W T}$ & DLogRM $3_{K W T}$ & $\begin{array}{c}0.028 * * * \\
(0.008)\end{array}$ & $\begin{array}{l}-0.046 \\
(0.077)\end{array}$ & 0.014 & 1.729 & 0.557 \\
\hline
\end{tabular}




\section{c. United Arab Emirates}

Table 7 displays the results for the models that test for the relationship between money supply and GDP, in nominal and real terms, in the Emirates. The M1, M2, and M3 monetary aggregates are all regressed separately and concurrently in both nominal and real terms for both variables.

Table 7. Results of UAE empirical model.

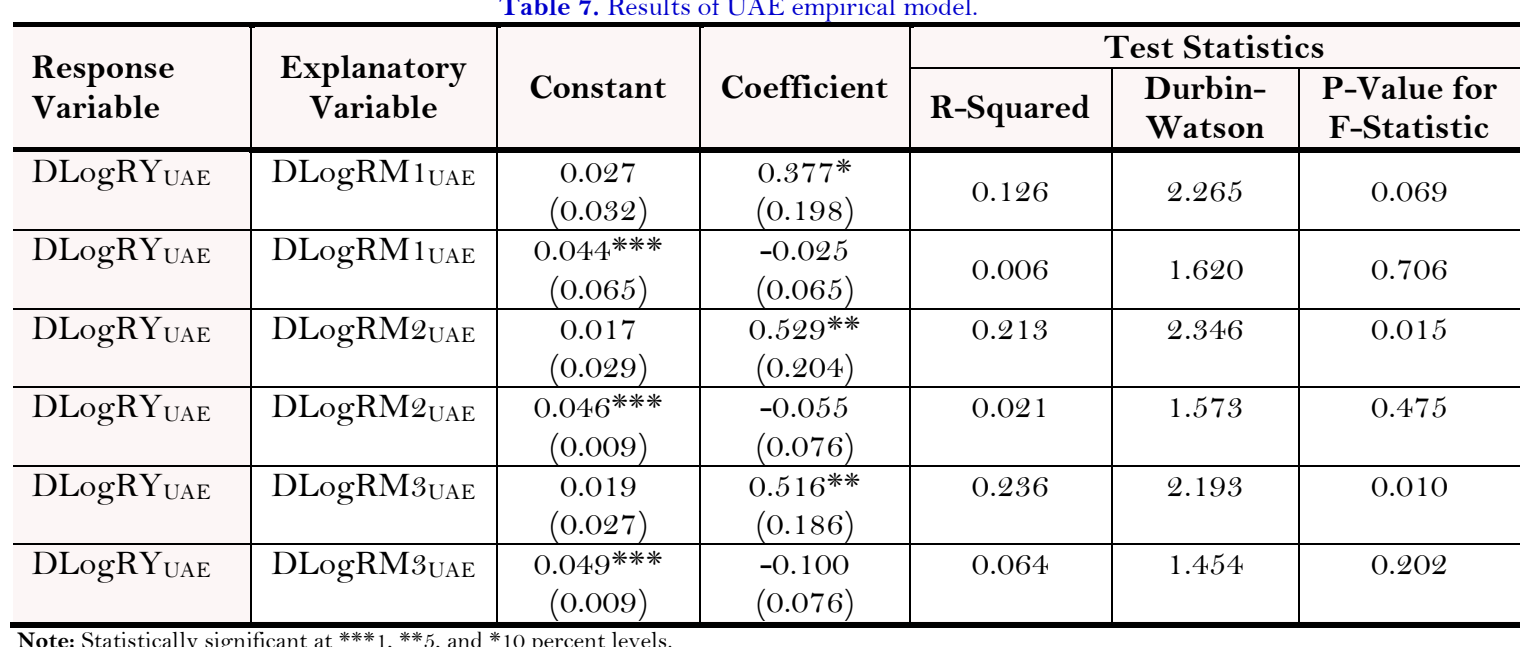

The output of the models in Table 7 show that, for the UAE, all monetary aggregates are significantly related to the GDP in nominal terms. However, no significant relationship is seen among the real-term models. Hameed and Amen (2011) found similar evidence of the impact of the money supply on the GDP in Pakistan.

As any other Central Bank, the prime objectives of the UAE Central Bank are to preserve the purchasing power of the national currency, as well as maintain growth and stability of the national economy. Defending the exchange rate against foreign currencies is among the secondary objectives of the Central Bank (Jumaa \& Tawdrous, 2019). These objectives can explain the significant relationship between the money supply M1 and the GDP. The Central Bank of the UAE decides the size of M1 to keep promoting economic growth. On the other hand, it strives to stabilize the exchange rate that is pegged to USD to keep attracting foreign deposits searching for a safer banking system removed from exchange rate volatility. These actions affect the M2 aggregate in the UAE, helping the country to achieve one of the central bank's goals of maintaining growth and stability of the economy.

Contrary to the cases of KSA and Kuwait, M3 in UAE shows evidence of a relationship with the GDP. Thus, we examine the components of M3 that are significant in the UAE model. Specifically, government deposits in the banks are positively significant with the GDP in UAE. It might be true that the monetary authorities in the country may enlarge $\mathrm{M} 3$ in an attempt to boost the economic growth by injecting liquidity into the banking system through deposits. However, none of the models estimated in real terms showed any significant relationship.

\section{CONCLUSION}

This paper has examined the relationship between the income or GDP and each of three monetary aggregates, M1, M2, and M3, in three Gulf countries, Saudi Arabia, Kuwait, and UAE. This study tests the variables in nominal and real terms, using the GDP deflator. This research tests initially for long-run cointegration between the variables, using the Johansen test for cointegration and the Engle-Granger Cointegration technique. Then, Granger causality is tested. Finally, reduced econometric models are estimated to test for evidence of the relationship between the variables. The results indicate similar findings in the four techniques applied. The results show evidence of a single cointegrating relationship between the GDP and M2 and GDP and M3 in KSA when applying the Engle-Granger test. Only one long-run relationship is seen among the GDP and M1 using the Johansen test. In UAE, the GDP and each of the monetary aggregates, M1, M2, and M3, show to be cointegrated, according to the Engle-Granger test, 
meanwhile some contradictions emerge when testing for the M1 money supply using the Johansen test. In Kuwait, no long-run relationship was observed between the variables when applying the Engle Granger test, except for a weak significant relationship between real GDP and real money supply presented by M1. This relationship is clearly not detected when applying the Johansen test due to the differing significance levels.

The Granger causality test could not prove any significant causality among the real term-variables. Yet, as far as the nominal terms are concerned, unidirectional Granger causality is the dominant pattern, and no bidirectional causality is observed. In particular, a significant unidirectional causality relationship is evident in Saudi Arabia for M1 Granger causing GDP, which itself Granger causes M3. Evidence from Kuwait showed unidirectional causality emerging from M1 towards GDP which in turn Granger causes both M2 and M3. Lastly, the bidirectional causality between GDP and M1 and MW in the UAE is considered unidirectional. This relationship is unidirectional, because the causality is not exchanged at the same lag. Thus, the unidirectional relationship is mainly from M1 towards GDP, M2 towards GDP, and GDP towards M1.

In the final step of this research, a linear regression is estimated to prove the nature of the relationship between the variables, after the preliminary tests are done. The GDP is assumed to be the dependent variable, whereas each of the three monetary aggregates are considered to be the independent variable. The estimated models prove, similar to the Granger causality tests, that for all three countries, no relationship is present at the real-term level between output or income and any of the money supply aggregates. Using nominal terms, the results are somewhat similar to the findings derived through the two preliminary tests applied. In the KSA models, the only evidence that a relationship is present is between GDP and M2, findings already indicated using the cointegration test. For Kuwait, the corresponding regressions show evidence that only M1 affects the GDP, as already shown through the Granger causality test. The UAE estimated equations show that all three monetary aggregates were affecting the GDP. These results are also confirmed by the cointegration tests and partially by the Granger causality tests.

From all of these mixed results, we can observe weak and not well supported evidence of the effect of money supply on income or GDP. These results would not support the Monetarists' view for the role of money in affecting economic activities, especially the output level. Finally, these results confirm the need for further studies investigating the relationship between income and money in the region.

Funding: This study received no specific financial support.

Competing Interests: The author declares that there are no conflicts of interests regarding the publication of this paper.

\section{REFERENCES}

Agbonlahor, O. (2014). The impact of monetary policy on the economy of the United Kingdom: A vector error correction model (VECM). European Scientific Journal, 10(16), 19-42.Available at: https://doi.org/10.19044/esj.2014.v10n 16p\%25p.

Ahmed, A. E. M., \& Suliman, S. Z. (2011). The long-run relationship between money supply, real GDP, and price level: Empirical evidence from Sudan. Journal of Business Studies Quarterly, 2(2), 68-79.

Al-Jasser, M., \& Al-Hamidy, A. (2004). A common currency area for the Gulf Region (pp. 116-120). BIS Papers No. 17.

Alawin, M. (2013). The relationship between military expenditure and economic growth, the case of Jordan. International Journal of Applied Business and Economic Research, 11 (1), 89-98.

Arltová, M., \& Fedorová, D. (2016). Selection of unit root test on the basis of length of the time series and value of AR (1) parameter. Statistical-Statistics and Economy Journal, 96(3), 47-64.

Asghar, Z. (2009). Simulation evidence on granger causality in presence of a confounding variable. International Journal of Applied Econometrics and Quantitative Studies, 5(2), 71-86.Available at: https://doi.org/10.1016/j.neuroimage.2009.11.060.

Aslam, A. L. M. (2016). Impact of money supply on Sri Lankan economy: An econometric analysis. International Letters of Social and Humanistic Sciences, 67, 11-17.Available at: https://doi.org/10.18052/www.scipress.com/ILSHS.67.1 . 
Babatunde, M. A., \& Shuaibu, M. I. (2011). Money supply, inflation and economic growth in Nigeria. Asian-African Journal of Economics and Econometrics, 11(1), 147-163.

Bălă, R.-M. (2014). Exploring the long-run relationship between GDP and private consumption of Romania through cointegration analysis. Ovidius University Annals, Economic Sciences Series, 14(1), 257-262.

Bilgili, F. (1998). Stationarity and cointegration tests: Comparison of Engle-Granger and Johansen methodologies. MPRA Paper No. 75967.

Chaitip, P., Chokethaworn, K., Chaiboonsri, C., \& Khounkhalax, M. (2015). Money supply influencing on economic growth-wide phenomena of AEC open region. Procedia Economics and Finance, 24, 108-115.

Dickey, D., \& Fuller, W. (1979). Distribution of the estimators for autoregressive time series with a unit root. Journal of the American Statistical Association, 74(366), 427-431.Available at: https://doi.org/10.1080/01621459.1979.10482531.

Durbin, J., \& Watson, G. (1950). Testing for serial correlation in least squares regression I. Biometrika, 37, 409-428.Available at: https://doi.org/10.2307/2332391.

Durbin, J., \& Watson, G. (1951). Testing for serial correlation in least squares regression II. Biometrika, 38, 159-178.Available at: https://doi.org/10.2307/2332391.

Engle, R., \& Granger, C. (1987). Cointegration and error correction: Representation, estimation, and testing. Econometrica, 55(2), 251-276.Available at: https://doi.org/10.2307/1913236.

Enyim, O., Onwe, G., \& Okoro, F. (2013). Monetary policy instruments and economic growth: Evidence from Nigeria. International Journal of Social Sciences and Humanities Revierws, 4(3), 1-15.

Gelo, T. (2009). Causality between economic growth and energy consumption in Croatia. Proceedings of the Faculty of Economics in Rijeka: Journal of Economics and Business, 27(2), 327-348.

Granger, C. (1969). Investigating causal relations by econometric models and cross-spectral methods. Econometrica, 37(3), 424438.

Hameed, I., \& Amen, U. (2011). Impact of monetary policy on gross domestic product (GDP). Interdisciplinary Journal of Contemporary Research Business, 3(1), 1348-1361.

Hasan, H. (2021). Dynamic analysis of economic growth, money supply, inflation and exchange rates: Using OLSs and VAR methods. International Journal of Economics, Business and Management Research, 5(6), 13-32.

Havi, E. D. K., \& Enu, P. (2014). The effect of fiscal policy and monetary policy on Ghana's economic growth: Which policy is more potent. International Journal of Empirical Finance, 3(2), 61-75.

Hussain, M. E., \& Haque, M. (2017). Fiscal deficit and its impact on economic growth: Evidence from Bangladesh. Economies, 5(4), 1-19.

Inam, U. S., \& Ime, B. S. (2017). Monetary policy and economic growth in Nigeria: Evidence from Nigeria. Advances in Social Sciences Research Journal, 4(6), 41-59.Available at: https://doi.org/10.14738/assrj.46.2806.

Ingabire, T., Uwineza, J., Benimana, M., Musafiri, F., Berimana, G., Ishimwe, N., \& Nshizirungu, N. (2020). Effect of money supply on economic growth in Rwanda. International Journal of Research and Innovation in Social Science, 4(6), 225-229.

Jawaid, S. T., Qadri, F. S., \& Ali, N. (2011). Monetary-fiscal-trade policy and economic growth in Pakistan: Time series empirical investigation. International Journal of Economics and Financial Issues, 1(3), 133-138.

Johansen, S. (1991). Estimation and hypothesis testing of cointegration vectors in Gaussian vector autoregressive models. Econometrica, 59(6), 1551-1580.

Jumaa, M., \& Tawdrous, M. (2019). Impact of the monetary policy on the UAE economic growth (Post Financial Crises). ChinaUSA Business Revierw, 18(1), 16-32.Available at: https://doi.org/10.17265/1537-1514/2019.01.002.

Kamaan, C. (2014). The effect of monetary policy on economic growth in Kenya. International Journal of Business and Commerce, $3(8), 11-24$.

Koopman, S. J., \& Lee, K. M. (2009). Seasonality with trend and cycle interactions in unobserved components models. Journal of the Royal Statistical Society: Series C (Applied Statistics), 58(4), 427-448.Available at: https://doi.org/10.1111/j.14679876.2009.00661.x. 
Lütkepohl, H., Saikkonen, P., \& Trenkler, C. (2001). Maximum eigenvalue versus trace tests for the cointegrating rank of a VAR process. The Econometrics Journal, 4(2), 287-310.Available at: https://doi.org/10.1111/1368-423X.00068.

Mansoor, A., Shoukat, Q., Bibi, S., Iqbal, K., Saeed, R., \& Zaman, K. (2018). The relationship between money supply, price level and economic growth in Pakistan: Keynesian versus Monetarist view. Review of Economic and Business Studies, 11(2), 4964.

Marzovilla, O., \& Mele, M. (2010). From dollar peg to basket peg: The experience of Kuwait in view of the GCC monetary unification. MPRA Paper No. 21605.

Masih, M., \& AbdulKarim, F. (2014). Dynamic causal chain of money, output, interest rate, exchange rate and prices: Nigeria as a case study. Munich Personal RePEc Archive, No. 58240.

Njimanted, F. G., Akume, D., \& Mukete, E. M. (2016). The impact of key monetary variables on the economic growth of the CEMAC zone. Expert Journal of Economics, 4(2), 54-67.

Omodero, C. (2019). Effect of money supply on economic growth: A comparative study of Nigeria and Ghana. International Journal od Social Science Studies, 7(3), 16-23.Available at: https://doi.org/10.11114/ijsss.v7i3.4137.

Precious, C., \& Makhetha-Kosi, P. (2014). Impact of monetary policy on economic growth: A case study of South Africa. Mediterranean Journal of Social Sciences, 5(15), 76-84.Available at: https://doi.org/10.5901/mjss.2014.v5n15p76.

Prihatin, W., Arintoko, \& Suharno. (2019). Analysis of the influence of monetary variables on Indonesian economic growth. Journal of Economics, Business, and Accounting, 21(3), 1-12.

Qadeer, M. (2016). Relationship between money supply, output and prices in India: An econometric exercise. The Empirical Economics Letters, 15(1), 65-73.

Senbet, D. (2011). The relative impact of fiscal versus monetary actions on output: A vector autoregressive (VAR) approach. Business and Economics Journal, 2(1), 1-11.

Sturgill, B. (2014). Money growth and economic growth in developed nations: An empirical analysis. Journal of Applied Business and Economics, $16(4), 41-52$.

Views and opinions expressed in this article are the views and opinions of the author(s), International Journal of Asian Social Science shall not be responsible or answerable for any loss, damage or liability etc. caused in relation to/arising out of the use of the content. 